\title{
O VALOR DO CORPO E AS LEIS DE MERCADO*
}

\author{
THE PRICE OF THE BODY AND MARKET LAWS
}

\section{Cíntia Rosa Pereira de Lima**}

\begin{abstract}
Resumo:
Este artigo ressalta alguns pontos problemáticos no tocante aos direitos de personalidade quanto à legalização do comércio de órgãos humanos. $\mathrm{O}$ objetivo é demonstrar que tal possibilidade contraria as bases filosóficas do ordenamento jurídico brasileiro, enfatizando o personalismo ético de Kant. Por fim, conclui-se que a doação de órgãos post mortem ou inter vivos deve ser sempre altruísta ou com fins científicos ou terapêuticos para que este procedimento esteja em plena harmonia com o art. $1^{\circ}$, inc. III da CF/88 (dignidade da pessoa humana) e art. 199, § $4^{\mathrm{o}}$ da CF/88 (vedação a comercialização de órgãos humanos). Por fim, ressalta-se a proteção dos direitos da personalidade no tocante à proibição de atos de disposição do próprio corpo que importem diminuição permanente da integridade física ou contrariar os bons costumes (art. 13 do $\mathrm{CC} / 02$ ), sendo a única possibilidade de disposição do próprio corpo a que tenha fim altruísta ou científico para depois da morte (art. 14 do CC/02) ou, em vida, desde que seja por razões terapêuticas dentro dos limites legais.
\end{abstract}

Palavras-chave: Doação de órgãos. Dignidade da pessoa humana. Personalismo ético (Kant). Mercado informal de órgãos humanos.

\begin{abstract}
:
This paper focuses on some questions about the human rights regarding the legalization of Soft Human Market. It aims to demonstrate that such act is against the philosophical basis of the Brazilian Law, specially the ethical personalism proposed by Immanuel Kant. Finally, the conclusion points that donation of human organs after death or by living donors must be always altruist or by scientific or therapeutic reasons so such procedure would be in harmony with the first article, III of Brazilian Constitution (that points out the human dignity) and article 199, $\S 4^{\circ}$ also from the Brazilian Constitution (that prohibits the commercialization of human organs). Summing up this paper points out the personality rights, specially the prohibition of acts that diminish permanently the physical integrity or contrary good faith (article 13 Brazilian Civil Code 2002), being the only possibility of doing so after death and with altruist or scientific purposes (article 14 Brazilian Civil Code 2002) or while alive if it is a therapeutic procedure within legal limits.
\end{abstract}

\footnotetext{
Trabalho apresentado na XX Semana Jurídica de Direito e Bioética da UNESP - Franca em 2010. Revisado e atualizado até 2012 .

** Doutora em Direito Civil pela Faculdade de Direito da Universidade de São Paulo, com estágio na Faculdade da Universidade de Ottawa (bolsa CAPES). Professora de Direito Civil da Faculdade de Direito de Ribeirão Preto da Universidade de São Paulo e da Pós-graduação em Direito Civil da Faculdade de Direito da Universidade de São Paulo.
} 
Keywords: Organs donation. Human dignity. Ethical personalism (Kant). Soflt Human Market.

\section{Introdução}

A sociedade pós-moderna enfrenta muitos conflitos polêmicos tendo em vista as possibilidades inovadoras viabilizadas pelos constantes avanços científicos. Além disso, o pluralismo religioso, moral e jurídico determina soluções distintas para a mesma situação. Por isso, que H. Tristram Engelhardt Jr. ${ }^{1}$ ressalta que a expressão inglesa Bioethics é utilizada no plural.

Neste contexto, surgiu o ramo denominado "Biodireito", cujo objeto é o estudo da bioética e das consequências jurídicas entre o Direito e os avanços tecnológicos relacionados à medicina e à biotecnologia. "Bioética", termo que foi utilizado pela vez primeira por Van Rensselder Potter, ${ }^{3}$ por sua vez, ressalta a busca do equilíbrio e da preservação dos seres humanos como parte de um ecossistema (parte de um todo).

Atualmente, "Bioética" consolidou-se como sendo a ciência que se dedica à moralidade da conduta humana na área das ciências da vida, impondo limites aos avanços científicos. ${ }^{4}$

Um dos limites impostos à ciência é a elevação do ser humano a uma posição central, ou seja, o ser humano é um fim em si mesmo ${ }^{5}$ não podendo ser estabelecido ao corpo humano, nem tão pouco às partes do corpo humano, valor monetário para fins comerciais. De outro lado, os avanços da medicina viabilizam a extração de órgãos humanos e a implantação destes em outros indivíduos com algum risco de rejeição, o que também está diminuindo face às substâncias medicinais que visam a reduzir os malefícios e ineficiência dos transplantes de órgãos humanos.

Por isso, em casos de doenças crônicas em que o transplante é a única solução, constata-se uma procura intensa por órgãos humanos. A demanda, hoje, é tão grande que o número de doadores, mortos ou vivos, não é suficiente. Assim, cresce a procura de órgãos humanos no mercado negro ou em países onde a comercialização de órgãos humanos é permitida.

ENGELHARDT JR., H. Tristram. The foundations of bioethics. 2. ed. New York: Oxford University Press, 1996. p. 9.

2 Neste sentido, leciona DINIZ, Maria Helena. O estado atual do biodireito. 2. ed. aum. e atual. conforme o Novo Código Civil (Lei n. 10.406/2002). São Paulo: Saraiva, 2002. p. 8.

3 POTTER, Van Rensselder. Bioethics: bridge to the future. New Jersey: Prentice-Hall, 1971.

4 DINIZ, Maria Helena. op. cit., p. 12.

5 Segundo doutrina de Emmanuel Kant Apud LARENZ, Karl. Derecho civil. Parte General. Trad. y notas de Miguel Izquierdo y Macías-Picaved. Madrid: Reunidas, 1978. p. 45. 
Em suma, a compra e venda de órgãos humanos está na ordem do dia, por representar uma ameaça aos valores éticos, religiosos, morais e jurídicos; portanto, requer uma atenção especial dos profissionais das mais diversas áreas.

2. A condição do ser humano na $\mathrm{CF} / 88$ :

O ser humano é o centro de gravidade do ordenamento jurídico. Assim, um dos princípios da República Federativa do Brasil é a dignidade da pessoa humana estampada no art. $1^{\circ}$, inc. III da $\mathrm{CF} / 88$ de onde emana o direito geral de personalidade.

Os seres racionais são denominados pessoas, consideradas um fim em si mesmas, nunca podendo ser tidas como meios. Desta forma, o imperativo ético fundamental de $\mathrm{Kant}^{6}$ resulta na dignidade que deve ser assegurada aos seres racionais, portanto, segundo tal acepção o corpo humano não tem valor monetário para fins comerciais. Assim, não pode ser objeto de comercialização o corpo humano ou partes do corpo humano.

Estes princípios são assegurados pela Magna Carta, apresentando, portanto conteúdo obrigatório. José Afonso da Silva ${ }^{7}$ afirma que: "princípios são ordenações que se irradiam e imantam os sistemas de normas, são [como observam Gomes Canotilho e Vital Moreira] 'núcleos de condensações' nos quais confluem valores e bens constitucionais."

Disto se infere que os princípios são obrigatórios e devem ser observados por todos, pois são espécies de normas. Além disso, estes princípios interferem em todo o ordenamento jurídico, Código Civil e leis especiais.

2.1. Princípio da dignidade da pessoa humana (art. $1^{\circ}$, inc. III da CF/88)

Este princípio é o ponto de partida para toda e qualquer análise jurídica, estampado como um dos fundamentos do Estado Democrático de Direito segundo consta do art. $1^{\circ}$, inciso III da $\mathrm{CF} / 88 .^{8}$

A dificuldade no estudo deste princípio está na ausência de um conceito apriorístico do que seja dignidade. Aliás, a noção deste princípio depende das circunstâncias histórico-culturais. Na visão de Kant, a pessoa humana não tem preço nem é substituível

LARENZ, Karl. op. cit., p. 45.

SILVA, José Afonso da. Curso de direito constitucional positivo. São Paulo: Revista dos Tribunais, 1998. p. 92.

8 TÍTULO I - Dos Princípios Fundamentais

Art. $1^{\circ}$ A República Federativa do Brasil, formada pela união indissolúvel dos Estados e Municípios e do Distrito Federal, constitui-se em Estado Democrático de Direito e tem como fundamentos: [...] III - a dignidade da pessoa humana; 
por equivalente. A pessoa não é coisa nem é meio; mas é um fim em si mesma, pelo que tem dignidade. ${ }^{9}$

O raciocínio de Kant está no fato de que a coisa tem valor relativo, ou seja, preço; o ser humano tem valor íntimo, isto é, dignidade (entendida como uma qualidade intrínseca de qualquer pessoa).

Günther Dürig, ${ }^{10}$ autor alemão, completando o raciocínio de Kant, afirma que a dignidade da pessoa humana poderia ser considerada atingida sempre que o indivíduo fosse rebaixado a objeto, a mero instrumento, tratado como coisa. Em outras palavras, sempre que for descaracterizado como sujeito de direito.

Destaca-se, então, a impossibilidade de atribuir um valor ao corpo humano, pois implicaria em sua redução a um objeto, atentando contra a dignidade da pessoa humana, assegurada em nível internacional.

A dignidade da pessoa humana é ressaltada no art. $1^{\circ}$ da Declaração Universal dos Direitos Humanos de 1948 da Assembleia Geral da ONU que diz: "todos os homens nascem livres e iguais em dignidade e direitos."

Já na década de 70, a Organização das Nações Unidas (ONU) emitiu uma Declaração sobre a Utilização do Progresso Científico e Tecnológico no Interesse da Paz e em Benefício da Humanidade - Res. 3.384, de 10 de novembro de 1975, ${ }^{11}$ ressaltando a dignidade da pessoa humana.

Jorge Miranda, ${ }^{12}$ professor na Universidade de Lisboa, diz que a dignidade é a fonte ética dos direitos, liberdades e garantias. Em outras palavras, é o valor fundante, ou seja, é o núcleo do qual gravitam os direitos fundamentais (é o valor maior). A dignidade aparece como fundamento e em razão disso, pode ser caracterizada como a fonte dos direitos fundamentais.

Assim, os avanços da medicina devem se nortear pelo princípio da dignidade da pessoa humana, harmonizando o bem estar do ser humano, sua segurança e os avanços científicos.

Aliás, o fundamento constitucional dos direitos da personalidade é a dignidade da pessoa humana, segundo aponta a doutrina. ${ }^{13} \mathrm{O}$ Código Civil francês, no art.

9 Apud QUEIROZ, Victor Santos. A dignidade da pessoa humana no pensamento de Kant. Da fundamentação da metafísica dos costumes à doutrina do direito. Uma reflexão crítica para os dias atuais. Jus Navigandi, Teresina, ano 9, n. 757, 31 jul. 2005. Disponível em: <http://jus2.uol.com.br/doutrina/texto.asp?id=7069>. Acesso em: 26 jul. 2009.

10 Apud GARCIA, Maria. Limites da ciência: a dignidade da pessoa humana: a ética da responsabilidade. São Paulo: Revista dos Tribunais, 2004. p. 199.

11 "Declaration sur l'utilisation du progrés de la science et de la technique dans l'intérêt de la paix au profit de l'humanité". (tradução livre). Disponível em: < http://daccessdds.un.org/doc/RESOLUTION/GEN/ NR0/002/77/IMG/NR000277.pdf?OpenElement>. Acesso em: 13 ago. 2008.

12 MIRANDA, Jorge. Manual de direito constitucional. 3. ed. rev. e atual. Coimbra: Ed. Coimbra, 1991. t. II e IV. p. 168-169.

13 NERY JÚNIOR, Nelson; NERY, Rosa Maria de Andrade. Código civil anotado e legislação extravagante. 
$16,{ }^{14}$ assegura a primazia da pessoa e a lei impede todos os atos atentatórios à dignidade da pessoa humana, garantindo o respeito do ser humano desde o começo de sua vida.

Neste sentido, portanto, a comercialização de partes do corpo humano não deve ser admitida pelo ordenamento jurídico brasileiro, por atentar contra a dignidade da pessoa humana.

\subsection{Personalismo ético}

O personalismo ético foi delineado por Immanuel Kant em sua obra "Fundamentos da Metafísica dos Costumes", enfatizado pela doutrina alemã, da qual se destaca Karl Larenz. ${ }^{15}$

E, também, pela doutrina brasileira, ${ }^{16}$ tanto o $\mathrm{CC} / 16$ (art. $2^{\circ}$ ), quanto o atual CC/02 (art. $\left.1^{\circ}\right)$ traz o "ser humano" ou a "pessoa", respectivamente, como ponto de partida da codificação. O que comprova a influência do pensamento de Kant por todo o mundo, notadamente nas codificações novecentistas.

Karl Larenz ${ }^{17}$ sintetiza com proficiência a doutrina kantiana nos seguintes termos:

El personalismo ético atribuye al hombre, precisamente porque es "persona" en sentido ético, un valor en sí mismo - no simplemente como medio para los fines de otros - y, en este sentido, una "dignidad". De ello se sigue que todo ser humano tiene frente a cualquier otro el derecho a ser respetado por el como persona, a no ser perjudicado en su existencia (la vida, el cuerpo, la salud) y en un ámbito propio del mismo y que cada individuo está obligado frente a cualquier otro de modo análogo.

Em síntese, a pessoa (ser humano) é um fim em si mesmo, ou seja, apresenta um valor absoluto. Neste sentido, não se pode atribuir um preço à pessoa humana, nem tão pouco, às partes do corpo humano. Portanto, a pessoa nunca deve ser encarada como um meio (ou uma coisa), que por sua vez tem valor relativo porque utilizado para suprir necessidades básicas dos seres humanos. Assim, não se admite que órgãos e

São Paulo: Revista dos Tribunais, 2003. p. 157.

14 “Art. 16. La loi assure la primaouté de la personne, interdit toute atteinte à la dignité de celle-ci et garantit le respect de l'être humain dès le commencemente de sa vie." (tradução livre)

15 LARENZ, Karl. op. cit., p. 44-102.

16 Vide AZEVEDO, Antônio Junqueira de. Crítica ao personalismo ético da Constituição da República e do Código Civil. Em favor de uma ética biocêntrica. In: ; TÔRRES, Heleno Taveira; CARBONE, Paolo. Princípios do novo código civil brasileiro e outros temas. Homenagem a Tulio Ascareli. São Paulo: Quartier Latin, 2008. p. 20-31.

17 LARENZ, Karl. op. cit., p. 45. 
tecidos humanos tenham um preço atribuído pelas leis de mercado, porque representa a coisificação do ser humano.

Ressalte-se que a doutrina moderna, o saudoso Professor Antônio Junqueira de Azevedo ${ }^{18}$ critica a visão tradicional do personalismo ético de Kant, porque o erro desta teoria "foi considerar que toda a vida não-humana, a vida em geral, e, em especial, a vida dos animais, era desprezível, sem dignidade, coisa!", o que fundamenta a destruição da natureza. Assim, o personalismo ético hoje deve ser atualizado para, mantendo o ser humano com valor absoluto garantindo sua dignidade, porém assegurando, além disso, proteção aos animais, que não devem mais ser vistos como coisas, mas como espécies que gozam de proteção legal haja vista as leis de proteção ao meio ambiente.

\subsection{Vedação de comercialização do corpo humano}

Diante de tudo o que foi exposto, acertadamente, o art. $199, \S 4^{\circ}$ da CF/88 veda todo tipo de comercialização de partes do corpo humano, in verbis:

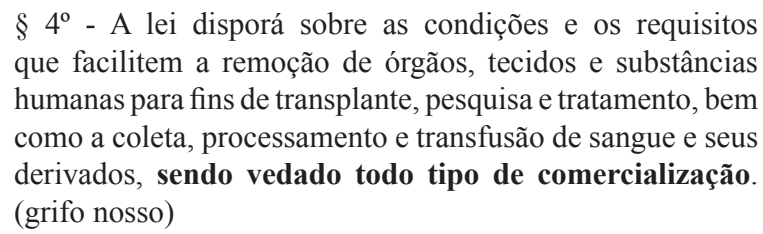

Ora, a lei mencionada pelo dispositivo constitucional é a Lei n. 9.434, de 04 de fevereiro de 1997, que regulamenta os transplantes de órgãos, impondo o caráter gratuito no seu art. $1^{0} \cdot{ }^{19}$ Ademais, a lei tipifica como crime a comercialização de órgãos humanos no art. $15 .^{20}$

Esta vedação está de acordo com o princípio da dignidade da pessoa humana e vai ao encontro das proposições kantianas acerca do personalismo ético. Caso contrário, ou seja, se fosse permitida a comercialização de órgãos humanos, o resultado seria a coisificação do ser humano.

O Código Civil de 2002, ao disciplinar os direitos de personalidade (art. 11 a 21), estabelece como limite à disposição de partes de corpo após a morte, desde que

18 AZEVEDO Antônio Junqueira de. op. cit., p. 21.

19 Artigo 1 - A disposição gratuita de tecidos, órgãos e partes do corpo humano, em vida ou post mortem, para fins de transplante e tratamento, é permitida na forma desta Lei.

Parágrafo único. Para os efeitos desta Lei, não estão compreendidos entre os tecidos a que se refere este artigo o sangue, o esperma e o óvulo.

20 Artigo 15 - Comprar ou vender tecidos, órgãos ou partes do corpo humano: Pena - reclusão de três a oito anos, e multa, de 200 a 360 dias-multa.

Parágrafo único - Incorre na mesma pena quem promove, intermedeia, facilita ou aufere qualquer vantagem com a transação. 
tenha fins altruístico ou científico; e, em vida, desde que tenha fins terapêuticos segundo o que dispõe a referida lei de transplante de órgãos.

No entanto, não se admite a hipótese em que o ser humano passe a ser visto como mercadoria, isto é inadmissível em nosso ordenamento jurídico. Diante disto, como harmonizar esta vedação e a possibilidade de transplantes de órgãos.

3. Transplantes de órgãos na Lei n. 9.434/97

Os transplantes começaram a ser realizados no Brasil na década de 60 . Nesta época surgiu a primeira norma brasileira sobre o tema, a Lei n. 4.280/63, criticada por apresentar uma normatização restrita acerca das "hipóteses de aproveitamento de órgão de cadáveres". Em outras palavras, permitiam-se apenas transplantes de órgãos originados de pessoas mortas.

Pouco tempo depois, esta lei é revogada pela Lei n. 5.479/68, que pretendeu corrigir algumas falhas da lei anterior, ao permitir em seu art. 10 a doação gratuita e para fins terapêuticos de seus órgãos por pessoa maior e capaz. Porém manteve-se a lacuna em se estabelecer um critério para diagnosticar a morte.

Assim, seguindo esta evolução, a Lei n. 8.489/92, regulada pelo Decreto n. 879/93, que insistiu na gratuidade da doação dos órgãos e tecidos humanos e na permissão de transplantes inter vivos, exigindo que o doador, nesta hipótese, seja maior e capaz.

Esta lei foi revogada pela atual Lei n. 9.434/97, regulamentada pelo Decreto n. 2.268 de 30 de junho de 1997, com as alterações da Lei n. 10.211/2001. Os pontos relevantes da atual legislação são: - a possibilidade do transplante post mortem mediante o diagnóstico da morte encefálica (art. $4^{\circ}$ da Lei n. 9.434/97 e Resolução n. 1.480/97 do Conselho Federal de Medicina); - o consentimento expresso para a doação post mortem, que pode ser deixada pelo próprio morto ou pelo cônjuge ou parente em linha reta ou colateral até o segundo grau; - permissão de transplantes inter vivos por pessoa capaz desde que sejam órgãos duplos ou partes renováveis do corpo humano (art. $9^{\circ}$ da Lei $n$ 9.434/97), ampliando esta possibilidade entre pessoas que não sejam ligadas por nenhum grau de parentesco desde que haja prévia autorização judicial; - gratuidade da doação em qualquer uma das hipóteses (art. $1^{\text {o }}$ da Lei n. 9.434/97); - organização do Sistema Nacional de Transplante (SNT), como órgão responsável pela captação e distribuição de órgãos, tecidos e partes do corpo humano (arts. $2^{\circ}$ a $5^{\circ}$ do Dec. n. 2.268/97), dentre outros.

Contudo, o principal questionamento diz respeito à harmonização da indisponibilidade do corpo humano, no todo ou em parte, com a possibilidade de doação de tecidos e órgãos humanos.

$\mathrm{Na}$ verdade, o direito admite a relativização da indisponibilidade do corpo humano (arts. 13 e 14 do CC/02), desde que seja feita de forma gratuita e sem prejuízo à vida e à saúde do doador, justificando-se por ser medida imprescindível para salvar a 
vida de outra pessoa ou preservar sua saúde como gesto altruísta e com fins terapêuticos e científicos.

\subsection{Transplantes de órgãos e tecidos post mortem}

Nos termos dos arts. $3^{\circ}$ e $4^{\circ}$ da Lei n. 9.434/97, é permitida a retirada de órgãos e tecidos humanos de indivíduos mortos, desde que seja diagnosticada a morte encefálica.

Nesta hipótese, não é atribuído valor ao corpo humano sem vida, pois este transplante somente deve ser admitido de forma gratuita nos termos do art. $1^{\mathrm{o}}$ da Lei n. 9.434/97, confirmado pelo art. 14 do Código Civil de 2002.

Importante ressaltar que a parte final do art. $4^{\circ}$ foi alterada pela Lei $n$. 10.211 de 2001, que não mais admite a doação presumida de órgãos e tecidos. A doação presumida de órgãos e tecidos significou grande inconveniente à sociedade à época, pois muitos indivíduos tiveram que manifestar sua vontade contrária em ser doador de forma expressa. Além disso, a doação de órgãos é um ato altruísta que decorre da vontade do indivíduo; por isso, requer-se manifestação expressa neste sentido e não presumida, o que não confere certeza da vontade do indivíduo em realmente ser doador. E, em última análise, aos menos informados, representaria uma imposição legal obrigando-o a doar seus órgãos, pois, desconhecendo tal consequência, não manifestou, em vida, sua vontade em não ser doador.

A captação e distribuição de tecidos e órgãos humanos são centralizadas em um único órgão em nível nacional, o Sistema Nacional de Transplantes (SNT) nos termos do art. $2^{\circ}$ da Lei n. 9.434/97. O SNT organiza uma fila nacional de indivíduos que necessitam receber tecidos e órgãos humanos.

Há um número extraordinário de pessoas na espera de um órgão vital, cerca de 60.000 indivíduos, que vivem na expectativa de ser seus últimos dias de vida ou, ao contrário, ter a sorte de existir doadores suficientes para que chegue até seu lugar na fila de transplantes. Devido ao baixo índice de doações de tecidos e órgãos humanos oriundos de cadáveres, cerca de 16 pessoas morrem por dia nas filas de espera de transplantes de órgãos. ${ }^{21}$

Esta expectativa gera um sofrimento imenso; além disso, a incerteza de que a pessoa irá receber o tecido e o órgão que necessita para sobreviver estimula a busca por órgãos e tecidos humanos na informalidade movida pelo instinto de sobrevivência.

${ }_{21}$ LAWAND JÚNIOR, Antônio Elian. Análise crítica do Sistema Nacional de Transplantes à luz da dignidade humana. In: MIGLIORE, Alfredo Domingues Barbosa; SCALQUETTE, Ana Cláudia; LIMA, Cíntia Rosa Pereira de; BERGSTEIN, Gilberto (Coord.). Dignidade da vida humana. São Paulo: LTr, 2010. p. 143. 


\subsection{Transplantes de órgãos inter vivos}

A outra modalidade de transplantes de órgãos e tecidos humanos dá-se inter vivos consoante o art. $9^{\circ}$ da Lei n. 9.434/97.

Os transplantes de órgãos e tecidos inter vivos restringem-se aos órgãos duplos (como os rins); às partes recuperáveis ou regeneráveis de órgãos (por exemplo, até $1 / 3$ do fígado, que leva entre 4 a 6 semanas para se regenerar); e tecidos (tais como a pele e a medula óssea).

Quando o doador e o receptor forem cônjuges ou parentes consanguíneos até o quarto grau, inclusive (primos), é dispensável a autorização judicial. Nestas circunstâncias, basta o diagnóstico médico que indica o transplante como a única solução e a manifestação expressa da vontade do doador. Estas doações são claramente movidas pelo sentimento altruísta e de afeto que une estes indivíduos.

Todavia, a Lei n. 9.434/97 conferiu maior amplitude ao transplante inter vivos, permitindo que seja feito entre pessoas sem nenhum grau de parentesco, desde que, para tanto, haja autorização judicial, com exceção do transplante de medula óssea que prescinde da atuação do Judiciário.

Ora esta abertura da lei tem sido a brecha necessária ao comércio ilegal de órgãos e tecidos humanos, isto porque doador e receptor, sem qualquer ligação de parentesco, fingem fazer o transplante de forma gratuita, quando, na verdade, o receptor pagou determinada quantia monetária pelo órgão que receberá. Daí a necessidade do Judiciário estar atento aos comportamentos, sentimentos e todos outros detalhes casuísticos que possam indiciar a existência do ilícito de compra de órgãos ou tecidos humanos.

Mas, ressalte-se, que ainda existindo esta brecha na lei, há pessoas que preferem fazer tudo na clandestinidade, arriscando sua vida, saúde e integridade física, submetendo-se a processos cirúrgicos de alto risco em clínicas não autorizadas pelo Poder Público, apresentando, então, precárias condições.

\subsection{Do transplante de órgãos no direito estrangeiro}

No direito estrangeiro, prevalece a gratuidade das doações de órgãos humanos. Na Europa, por exemplo, a Recomendação n. 29/78 (arts. $9^{\circ}$ e 14) impõe a gratuidade nos transplantes de órgãos humanos.

Nos Estados Unidos, a lei denominada National Organ Transplant Act também determina a gratuidade:

It shall be unlawful for any person to knowingly acquire, receive, or otherwise transfer any human organ for valuable consideration for use in human transplantation if the transfer affects interstate commerce. 
Assim, de maneira generalizada, pode-se afirmar que a regra é a gratuidade das doações de órgãos. Portanto, trata-se de um gesto essencialmente altruísta, afastando qualquer interesse mercadológico da doação de órgãos.

Não obstante, em alguns países, como a Índia, permite-se a comercialização de determinados órgãos.

4. Características da doação de órgãos

Diante destas observações, ressaltam-se algumas características dos transplantes de órgãos e tecidos humanos.

Primeira, é a solidariedade que inspira toda a regulamentação legal dos transplantes de órgãos e tecidos humanos fundado no Princípio da Solidariedade (art. $3^{\circ}$, inc. I da CF/88). Além disso, a solidariedade inspira o próprio sentimento individual de fazer tamanho bem a outrem, ainda que lhe cause certo sofrimento. É o fenômeno apontado pelo saudoso professor Antonio Junqueira de Azevedo ${ }^{22}$ como solidariedade grupal, entendido como “"...] um impulso físico de defender os semelhantes; esta solidariedade é própria dos animais superiores e também se revela nos seres humanos, dando origem a muitas regras jurídicas".

Outra característica da doação de órgãos é ser um ato personalíssimo e como tal a exteriorização da manifestação em doar um de seus órgãos deve ser precedida de todos e quaisquer esclarecimentos que se façam necessários, ou seja, enfatiza-se a necessidade do consentimento informado. ${ }^{23}$

Excepcionalmente, o cônjuge ou parente maior e capaz até o segundo grau (terá preferência o primeiro na linha sucessória reta ou colateral) pode dar autorização para o transplante de órgãos e tecidos do de cujus (art. $4^{\circ}$ da Lei de Transplantes de Órgãos). É uma medida de política legislativa porque é cediço que o ser humano não costuma pensar no fim de sua existência e nas consequências para depois de sua morte. Por outro lado, a espera por um órgão é muito longa em razão dos escassos doadores. Por fim, entende-se que estes parentes mais próximos (até o $2^{\circ}$ grau) conhecem bem o de cujus para poder prever que a doação seria de sua vontade.

Além de ser um ato solidário e altruísta, este ato deve ser revestido de gratuidade (art. $1^{\circ}$ da Lei n. 9.434/97). Não se admite a compra e venda de tecidos ou órgãos humanos, por atentar contra a dignidade da pessoa humana reduzindo-a a coisa com valor relativizado ("coisificação do ser humano").

22 AZEVEDO, Antônio Junqueira de. op. cit., p. 25.

23 DINIZ, Maria Helena. op. cit., p. 287. 
Por fim, o ato através do qual se manifesta a vontade em ser doador é revogável a qualquer tempo antes do transplante, nos termos do $\S 5^{\circ}$ do art. $9^{\circ}$ da Lei n. 9.434/97 e parágrafo único do art. 14 do CC/02.

\section{Mercado de partes do corpo humano ("Soft Human Market")}

Como foi exposto acima, não se admite a comercialização de órgãos humanos no Brasil e, de forma generalizada, na Europa e América do Norte. Entretanto, é inegável que existe, na informalidade, mercado de partes do corpo humano.

Dentre as razões citadas pela doutrina, ${ }^{24}$ citam-se: - as desigualdades sociais e a situação de miséria especialmente dos "falsos doadores", que vendem seus órgãos em busca de melhor qualidade de vida; - por outro lado, a esperança de melhor qualidade de vida do receptor, que necessita do órgão para sua sobrevivência e não pode esperar longos anos na fila do transplante o que, fatalmente, levaria à morte; - o alto custo de tratamento de saúde (e.g. diálise), o que não deixa de ser um fator determinante para que o indivíduo opte pelo transplante; além disso, tais tratamentos geralmente são muito dolorosos e ineficazes; - e, por fim, a longa espera na fila de transplantes, o que gera uma situação de desespero do indivíduo que necessita ser transplantado e, por isso, acabe optando pela compra ilegal e transplante clandestino.

Diante à inegável existência da compra e venda de órgãos humanos, há posições favoráveis e contrárias à legalização do comércio de órgãos.

\subsection{Argumentos contrários à legalização do comércio de órgãos}

Nancy Scheper-Hughes ${ }^{25}$ é contra a legalização do comércio de órgãos humanos, pois isto só beneficiará os indivíduos que têm boas condições financeiras.

Os religiosos, de forma geral, são contrários à legalização, pois o corpo como criação divina não pode ser comercializado. Neste sentido, o Papa João Paulo II ${ }^{26}$ alerta que a legalização do comércio de órgãos humanos atenta contra a dignidade da pessoa humana.

$24 \quad$ Id. Ibid., p. 295.

25 Living kidney donation: controversies and realities: organs without borders: open markets, closed systems and the global search for living donors. Program and abstracts of the American Transplant Congress 2005. In: Sixth Annual Joint Meeting of the American Society of Transplant Surgeons and the American Society of Transplantation. Seattle (Wa), 21 a 25 de maio de 2005. Disponível em: <http://www3.interscience.wiley. com/journal/118717694/abstract>. Acesso em: 07 abr. 2010.

26 Encyclical Letter To the Bishops Priests and Deacons Men and Women religious lay Faithful and all People of Good Will on the Value and Inviolability of Human Life on the value and inviolability of human life. 25 de março de 1995. Disponível em: <http://www.vatican.va/holy_father/john_paul_ii/encyclicals/documents/ hf_jp-ii_enc_25031995_evangelium-vitae_en.html>. Acesso em: 07 abr. 2010. 
Francis Leo Delmonico ${ }^{27}$ também não admite a legalização do comércio de órgãos humanos, pois o doador empobrecerá ainda mais custeando tratamentos de saúde caros, ou seja, este ato seria o domínio legalizado dos ricos sobre os pobres.

Acrescentamos que esta legalização contraria todo o ordenamento jurídico brasileiro, estando literalmente vedada pelo $\S 4^{\circ}$ do art. 199 da CF/88. Muito embora este dispositivo não seja cláusula pétrea nos termos do art. $60, \S 4^{\circ}$, da $\mathrm{CF} / 88$, sustentamos que a indisponibilidade do corpo humano decorre do caput do art. $5^{\circ}$ da $\mathrm{CF} / 88$, que é cláusula pétrea. Assim, se o corpo humano é inviolável, não se pode admitir que um órgão humano fosse objeto de negociação. Portanto, nem por emenda à constituição pode-se instituir à legalização do comércio de órgãos humanos.

\subsection{Argumentos favoráveis à legalização do comércio de órgãos}

Arthur Matas ${ }^{28}$ sustenta, ao contrário, a legalização da compra e venda de órgãos humanos, pois isto reduziria o número de mortes daqueles que esperam na fila de transplantes.

Além dele, Michael Finkel ${ }^{29}$ acrescenta que a venda de órgãos (especialmente rins) é uma realidade em diversos países, tais como, Índia, Turquia, China, Rússia e América do Sul. Assim, é um absurdo fingir que nada acontece e manter a proibição legal.

Robert Berman, ${ }^{30}$ no mesmo sentido, enfatiza que a comercialização de órgãos humanos é uma realidade que necessita de regulamentação legal.

Em suma, pode-se resumir esta discussão demonstrando suas vantagens e desvantagens.

As principais vantagens da legalização do comércio de órgãos seriam: maior autonomia sobre o seu corpo; - acabaria com as distorções de preços; - desestímulo ao mercado negro; - salvaria mais vidas.

Por outro lado, as desvantagens são muitas e, a nosso ver, mais desastrosas: o desestímulo de doações altruístas; - a patrimonialização do ser humano; - a manipulação econômica da alocação de órgãos; - o aumento de homicídios de potenciais doadores.

27 The House Committee on Energy and Commerce. Assessing Initiatives to Increase Organ Donations. Subcommittee on Oversight and Investigations. Washington: Committee on Energy and Commerce 3 de junho de 2003. Disponível em: <http://catalogue.nla.gov.au/Record/4169968>. Acesso em: 07 abr. 2010.

28 Living kidney donation: controversies and realities: organs without borders: open markets, closed systems and the global search for living donors. Program and abstracts of the American Transplant Congress 2005. In: Sixth Annual Joint Meeting of the American Society of Transplant Surgeons and the American Society of Transplantation. Seattle (Wa), 21 a 25 de maio de 2005. Disponível em: $<\mathrm{http}: / / \mathrm{www} 3$.interscience.wiley. com/journal/118717694/abstract>. Acesso em: 07 abr. 2010.

29 This little kidney went to market. In: New York Times Magazine, 27 de maio de 2001. Disponível em: $<$ http://www.nytimes.com/2001/05/27/magazine/27ORGAN.html?pagewanted=1\&pagewanted=print $>$. Acesso em: 07 abr. 2010.

30 Selling organs should be legal. In: Jerusalem Post, 9 de agosto de 2005. Disponível em: <http://www.hods. org/pages/press/JPost9Aug05.htm>. Acesso em: 07 abr. 2010. 


\subsection{O corpo humano tem preço?}

Preliminarmente deve-se notar que o vocábulo "valor" é ambíguo, pois pode ser utilizado em diversas acepções. Na definição trazida pelo dicionário, "valor" é determinado como: ${ }^{31}$

sm (lat valore) $1 \mathrm{O}$ preço atribuído a uma coisa; estimação, valia. 2. Relação entre a coisa apreciável e a moeda corrente no país, em determinada época e em determinado lugar. 3. Filos Caráter dos seres pelo qual são mais ou menos desejados ou estimados por uma pessoa ou grupo. 4. Econ polít Estimativa econômica da riqueza. 5. Econ polít Apreciação feita pelo indivíduo da importância de um bem, com base na utilidade e limitação relativa da riqueza, e levando em conta a possibilidade de sua troca por quantidade maior ou menor de outros bens. 6. Mat Expressão numérica ou algébrica que determina uma incógnita ou representa o estado de uma variável. 7. Dir Qualidade que tem o ato jurídico de produzir determinado efeito. 8. Talento. 9. Coragem, esforço de ânimo, intrepidez, valentia. 10 Paciência, resignação. 11. Merecimento, préstimo, valia. 12 Qualidade do que tem força. 13. Papel representativo de dinheiro (nota de banco, título, obrigação, ação, letra de câmbio). [...]

Em última análise, a palavra "valor" pode ser empregada sob vários enfoques. Por exemplo, o enfoque sentimental ressalta a importância de algo a uma pessoa; o enfoque econômico designa a relação entre um bem e o valor monetário de um país; o enfoque jurídico, por sua vez, estabelece os efeitos de um ato jurídico e assim por diante.

Todavia, quando se fala em "preço", por sua vez, quer-se dizer a atribuição de um valor monetário a uma mercadoria ou serviço. ${ }^{32}$ Neste sentido, há várias teorias econômicas sobre fixação do preço.

O economista Gary S. Becker, vencedor do prêmio Nobel de Economia em 1992, em conjunto com Julio Jorge Elías ${ }^{33}$ estabeleceram um cálculo para apreciar o valor de um órgão humano. Sendo o ganho anual de um americano de $\$ 40.000$ (quarenta mil dólares); o valor da vida, então, é de aproximadamente $\$ 3$ (três) milhões de dólares; o risco de morte em decorrência de doença renal gira em torno de 1\%; a perda da qualidade

31 Disponível em: $\quad<$ http://michaelis.uol.com.br/moderno/portugues/index.php?lingua=portuguesportugues\&palavra=valor $>$. Acesso em: 07 abr. 2010.

32 "sm (lat pretiu) 1 Valor em dinheiro de uma mercadoria ou de um trabalho; custo. 2 Dir Prestação pecuniária determinada na compra e venda, expressa em moeda ou valor fiduciário, paga pelo comprador ao vendedor. 3 Aquilo que se dá, se sacrifica ou se obtém em troca de alguma coisa. [...]”"

33 Introducing Incentives in the Market for Live and Cadaveric Organ Donations. In: Conference on Organ Transplantation: Economic, Ethical and Policy Issues, University of Chicago. 16 de maio de 2003. Disponível em: <http://home.uchicago.edu/ gbecker/papers/papers.html>. Acesso em: 07 abr. 2010. 
de vida em decorrência de uma doença renal é de 5\%; os gastos com saúde em decorrência da venda do rim seria em média de $\$ 7000$ (sete mil dólares). Assim, o valor de um rim para compra pode ser fixado em $\$ 45000$ (quarenta e cinco mil dólares).

Todavia, não se pode concordar com esta teoria, pois conferir um preço ao corpo humano ou a um órgão humano é, em última análise, encará-lo como mercadoria o que contraria a própria dignidade da pessoa humana, fundamento constitucional da República Federativa do Brasil.

\section{Crime de Compra e Venda de Órgãos}

Além da vedação constitucional de comprar ou vender órgãos humanos e o art. $1^{\circ}$ da Lei n. 9.434/97 impor a gratuidade nas doações de órgãos e da proteção e tutela dos direitos da personalidade do CC/02, o art. 15 da Lei n. 9.434/97 tipificou a compra-evenda de tecidos e órgãos humanos como crime.

Todavia, na prática, é extremamente difícil obter a prova deste crime realizado em um contexto de tráfico internacional, o que dificulta demasiadamente a obtenção de elementos probatórios suficientes para a condenação dos envolvidos. Por isso, há poucos julgados neste sentido, que, inclusive ressaltam a dificuldade probatória:

[...] 3. Na hipótese, os fatos tidos por delituosos se iniciavam no Brasil, com os procedimentos relacionados ao recrutamento e seleção dos doadores, bem como a realização dos exames preliminares, enquanto o resultado deveria ocorrer na África do Sul, onde seriam realizados os exames complementares e a realização da extração dos órgãos humanos. Em sendo assim, resta evidenciada a competência da Justiça Federal para o processamento e julgamento da causa em questão.

4. As questões referentes à ilicitude das provas produzidas, à apreensão de documentos com violação de domicílio e uso indevido de provas emprestadas, não foram objeto de análise no acórdão ora hostilizado, razão pela qual não há como serem conhecidas, diante da flagrante incompetência desta Corte Superior Tribunal de Justiça para apreciar originariamente a matéria, sob pena de supressão de instância. Precedente desta Corte.

5. Habeas corpus conhecido parcialmente e, na parte conhecida, denegada a ordem.

(HC 58.120/PE, Rel. Ministra LAURITA VAZ, QUINTA TURMA, julgado em 27/03/2008, DJe 22/04/2008)

Percebe-se que o modos operandi é selecionar órgãos de brasileiros que são comprados no "mercado negro" e transplantados em outro país, como no continente africano. 
Em suma, verificadas as circunstâncias que comprovam a existência de tráfico de órgãos humanos, os indivíduos fatalmente serão condenados.

HABEAS CORPUS. PROCESSUAL PENAL. CRIMES DE TRÁFICO DE ÓRGÃOS HUMANOS E DE FORMAÇÃO DE QUADRILHA. REGIME PRISIONAL MAIS GRAVOSO (FECHADO).

LEGALIDADE. CIRCUNSTÂNCIAS JUDICIAIS DESFAVORÁVEIS. PENA-BASE FIXADA ACIMA DO MÍNIMO LEGAL. INTELIGÊNCIA DOS ARTS. 59 E 33, § 2. ${ }^{\circ}$, DO CÓDIGO PENAL.

1. Demonstrada pela sentença monocrática a existência de circunstâncias judiciais desfavoráveis ao condenado, é possível a fixação da pena-base acima do mínimo legal, assim como a imposição de regime prisional mais gravoso, em decorrência da interpretação conjunta dos arts. 59 e 33, § 2. ${ }^{\circ}$, ambos do Código Penal.

Precedentes do STJ.

2. Ordem denegada.

(HC 46.082/PE, Rel. Ministra LAURITA VAZ, QUINTA TURMA, julgado em 12/09/2006, DJ 06/11/2006 p. 348)

6.1. Análise do tema no direito estrangeiro:

A criminalização de órgãos humanos é uma opção política, assim, em alguns países permite-se a compra e venda de órgãos humanos.

Por exemplo, na Índia, o comércio de órgãos e tecidos humanos é legal desde 1994; todavia, somente se admite a venda de órgãos duplos, como rins. ${ }^{34}$

$\mathrm{Na}$ China, admitia-se a venda de órgãos dos presos executados em razão de condenação à morte. Entretanto, hoje isto não é mais admitido. ${ }^{35}$

No Iran, é legal a venda de rins, sendo que um rim custa em média \$7,500 (sete mil e quinhentos dólares), ${ }^{36}$ muito abaixo da estimativa idealizada pelos economistas Gary S. Becker e Julio Jorge Elias; provavelmente em razão da legalização.

Este cenário internacional estimula o que se denomina "Transplant Tourism", ou seja, pessoas que residam em um país onde é ilegal a compra e venda de órgãos humanos viajam para um país onde tal conduta é permitida para comprar um órgão e serem transplantadas. Por isso, organizações internacionais mobilizam para conscientizar a sociedade dos inconvenientes destes procedimentos.

34 GOVERNO DA ÍNDIA. Transplantation of Human Organs Act, 1994. Central Act 42 of 1994. Disponível em: <http://www.medindia.net/tho/thobill1.asp>. Acesso em: 07 abr. 2010.

35 MCGIVERING, Jill. China 'selling prisoners'organs'. In: BBC News. Disponível em: <http://news.bbc. co.uk/go/pr/fr/-/2/hi/asia-pacific/4921116.stm>. Acesso em: 07 abr. 2010.

36 GHODS, Ahad J.; SAVAJ, Shekoufeh. Iranian Model of Paid and Regulated Living-Unrelated Kidney Donation. Disponível em: <http://cjasn.asnjournals.org/cgi/rapidpdf/CJN.00700206v1.pdf>. Acesso em: 07 abr. 2010. 
Mas o comércio de órgãos e tecidos humanos não se restringe aos órgãos e tecidos oriundos de pessoas adultas ou crianças; cresce a procura por tecidos embrionários ou fetais que apresentam menor índice de rejeição.

7. Utilização de tecidos e órgãos embrionários ou fetais:

A discussão acerca da legalização ou não da venda de órgãos humanos acentuou os debates sobre a possibilidade de utilizar tecidos e órgãos embrionários ou fetais. Este foi o pano de fundo da Ação Direta de Inconstitucionalidade, ADI n. 3510, em que se pretendeu declarar inconstitucional o art. $5^{\circ}$ da Lei n. 11.105/2005, pois permite para fins de pesquisa e terapia a utilização de células-tronco embrionárias resultantes de fertilização in vitro e não utilizadas no procedimento.

A utilização de células-tronco apresenta muitas vantagens, a mais importante é a maior facilidade de adaptação e, portanto, menos riscos de rejeição.

Todavia, a desvantagem de se admitir a compra e venda de órgãos e tecidos fetais está na coisificação do embrião ou feto, afrontando a dignidade da pessoa humana. ${ }^{37}$ No entanto, concordamos com Antônio Junqueira de Azevedo ${ }^{38}$ sobre a acertada decisão do Supremo Tribunal Federal ${ }^{39}$ que declarou constitucional o art. $5^{\circ}$ da Lei de Biossegurança. Ressaltamos, porém, que a utilização destes tecidos e órgãos justifica-se apenas por ato altruísta e com fins terapêuticos ou científicos; mas nunca como mercadoria que possa ser comercializada.

DINIZ, Maria Helena. op. cit., p. 291.

AZEVEDO Antônio Junqueira de. op. cit., p. 25.

39 PLENÁRIO - ADI e Lei da Biossegurança - 6: "Em conclusão, o Tribunal, por maioria, julgou improcedente pedido formulado em ação direta de inconstitucionalidade proposta pelo Procurador-Geral da República contra o art. $5^{\circ}$ da Lei federal 11.105/2005 (Lei da Biossegurança), que permite, para fins de pesquisa e terapia, a utilização de células-tronco embrionárias obtidas de embriões humanos produzidos por fertilização in vitro e não usados no respectivo procedimento, e estabelece condições para essa utilização - v. Informativo 497. Prevaleceu o voto do Min. Carlos Britto, relator. Nos termos do seu voto, salientou, inicialmente, que o artigo impugnado seria um bem concatenado bloco normativo que, sob condições de incidência explícitas, cumulativas e razoáveis, contribuiria para o desenvolvimento de linhas de pesquisa científica das supostas propriedades terapêuticas de células extraídas de embrião humano in vitro. Esclareceu que as célulastronco embrionárias, pluripotentes, ou seja, capazes de originar todos os tecidos de um indivíduo adulto, constituiriam, por isso, tipologia celular que ofereceria melhores possibilidades de recuperação da saúde de pessoas físicas ou naturais em situações de anomalias ou graves incômodos genéticos. Asseverou que as pessoas físicas ou naturais seriam apenas as que sobrevivem ao parto, dotadas do atributo a que o art. $2^{\circ}$ do Código Civil denomina personalidade civil, assentando que a Constituição Federal, quando se refere à 'dignidade da pessoa humana' (art. $1^{\circ}$, III), aos 'direitos da pessoa humana' (art. 34, VII, b), ao 'livre exercício dos direitos individuais' (art. 85, III) e aos 'direitos e garantias individuais' (art. 60, § 4’, IV), estaria falando de direitos e garantias do indivíduo-pessoa. Assim, numa primeira síntese, a Carta Magna não faria de todo e qualquer estádio da vida humana um autonomizado bem jurídico, mas da vida que já é própria de uma concreta pessoa, porque nativiva, e que a inviolabilidade de que trata seu art. $5^{\circ}$ diria respeito exclusivamente a um indivíduo já personalizado. ADI 3510/DF, rel. Min. Carlos Britto, 28 e 29.5.2008. (ADI-3510)" Disponível em: < http://www.stf.jus.br/arquivo/informativo/documento/informativo508.htm>. Acesso em: 07 abr. 2010. 
8. Doação de órgãos e tecidos por presidiários como causa de diminuição de pena

Destacou-se, supra, que em países onde a pena de morte é admitida, questionou-se a possibilidade de doar órgãos por presidiários condenados à morte. $\mathrm{Na}$ China, por exemplo, era possível. Hoje não mais.

No Brasil, tal hipótese seria inadmissível, pois se veda a pena de morte (art. $5^{\circ}$, inc. XLVII, “a” c/c art. 60, $\S 4^{\circ}$, inc. IV da CF/88). Todavia, nada impede que o presidiário voluntariamente, em não em virtude de lei, opte em doar seus órgãos de forma altruísta após sua morte.

Inter vivos, a doação de órgãos por presidiários imposta por lei em troca de uma possível redução da pena, também, é inadmissível, porque equivaleria a um pagamento; ou seja, uma permuta entre pedaço do corpo por um desconto no tempo de pena.

A doação deve ser sempre voluntária, por isso, em tese é admissível que voluntariamente um presidiário opte em doar um órgão duplo a um parente consanguíneo até o quarto grau inclusive de forma altruísta.

Contudo, Maria Helena Diniz ${ }^{40}$ adota um posicionamento contrário, pois a psicose carcerária reduz a autonomia de vontade do preso o que deslegitima qualquer manifestação de vontade do presidiário.

\section{Conclusão}

Sistematicamente, a comercialização de órgãos humanos é vedada pela grande maioria dos países, incluindo o Brasil. Isto porque se percebe a forte influência do personalismo ético de Kant, que impõe o ser humano com valor absoluto, isto é, como fim e nunca como meio. Assim, permitir a venda de um órgão humano, atribuindo-lhe um preço implica na coisificação do ser humano, atentando contra a dignidade da pessoa humana.

A grande questão que está na ordem do dia é: será que a comercialização de órgãos realmente salvaria vidas?

Não acreditamos nisso, pois a legalização da compra e venda de órgãos humanos somente beneficia a camada economicamente mais favorecida. Ora, os custos que envolvem um transplante, além do preço do órgão em si, são caríssimos, por isso, apenas uma pequena parcela da população seria beneficiada pela legalização da compra e venda de órgãos humanos. Aliás, é este o resultado nos países em que a compra e venda de órgãos duplos, como rins, é permitida por lei (Índia e Iran).

40 DINIZ, Maria Helena. op. cit., p. 293-294. 
Neste sentido, Nancy Scheper-Hughes ${ }^{41}$ afirma que permitir a compra e venda de órgãos humanos é autorizar a camada privilegiada de a sociedade reivindicar direito de propriedade sobre os corpos de indivíduos carentes.

É consenso que a compra e venda de órgãos é ilegal e antiética. A venda de órgãos não resolve a situação financeira do doador, que terá mais gastos com saúde. E, tão-pouco, seria utilizada por todos que necessitam de um órgão, pois muitos destes não têm recursos financeiros para tanto. Sendo impossível exigir do Estado o custeio destes tratamentos às camadas menos favorecidas.

Deve-se estimular, portanto, as doações de órgãos altruístas através de políticas públicas.

São Paulo, dezembro de 2012.

\section{Referências}

AZEVEDO, Antônio Junqueira de. Crítica ao personalismo ético da Constituição da República e do Código Civil. Em favor de uma ética biocêntrica. In: ; TÔRRES, Heleno Taveira; CARBONE, Paolo. Princípios do novo código civil brasileiro e outros temas. Homenagem a Tulio Ascareli. São Paulo: Quartier Latin, 2008.

BECKER, Gary S.; ELÍAS, Julio Jorge. Introducing Incentives in the Market for Live and Cadaveric Organ Donations. In: Conference on Organ Transplantation: Economic, Ethical and Policy Issues, University of Chicago. 16 de maio de 2003. Disponível em: <http://home.uchicago.edu/ gbecker/ papers/papers.html>. Acesso em: 07 abr. 2010.

BERMAN, Robert. Selling organs should be legal. In: Jerusalem Post, 9 de agosto de 2005. Disponível em: <http://www.hods.org/pages/press/JPost9Aug05.htm>. Acesso em: 07 abr. 2010.

DELMONICO, Francis Leo. The House Committee on Energy and Commerce. Assessing Initiatives to Increase Organ Donations. Subcommittee on Oversight and Investigations. Washington: Committee on Energy and Commerce 3 de junho de 2003. Disponível em: <http://catalogue.nla. gov.au/Record/4169968>. Acesso em: 07 abr. 2010.

DINIZ, Maria Helena. O estado atual do biodireito. 2. ed. aum. e atual. com o novo Código Civil (Lei n. 10.406/2002). São Paulo: Saraiva, 2002.

ENGELHARDT Jr., H. Tristram. The foundations of bioethics. 2. ed. New York: Oxford University Press, 1996.

${ }^{41}$ Op. cit., documento em meio eletrônico sem paginação: "permitting legal solid organ sales would permit one relatively privileged population [to] claim property rights over the bodies of the disadvantaged". (tradução livre) 
FINKEL, Michael. This little kidney went to market. In: New York Times Magazine, 27 de maio de 2001. Disponível em: <http://www.nytimes.com/2001/05/27/magazine/27ORGAN.html?pagewant ed=1\&pagewanted=print $>$. Acesso em: 07 abr. 2010.

GARCIA, Maria. Limites da ciência: a dignidade da pessoa humana: a ética da responsabilidade. São Paulo: Revista dos Tribunais, 2004.

GOVERNO DA ÍNDIA. Transplantation of Human Organs Act, 1994. Central Act 42 of 1994. Disponível em: <http://www.medindia.net/tho/thobill1.asp>. Acesso em: 07 abr. 2010.

QUEIROZ, Victor Santos. A dignidade da pessoa humana no pensamento de Kant. Da fundamentação da metafísica dos costumes à doutrina do direito. Uma reflexão crítica para os dias atuais. Jus Navigandi, Teresina, ano 9, n. 757, 31 jul. 2005. Disponível em: <http://jus2.uol.com.br/doutrina/ texto.asp?id=7069>. Acesso em: 26 jul. 2009.

LARENZ, Karl. Derecho civil. Parte general. Trad. y notas de Miguel Izquierdo y Macías-Picaved. Madrid: Reunidas, 1978.

LAWAND JÚNIOR, Antônio Elian. Análise crítica do Sistema Nacional de Transplantes à luz da dignidade humana. In: MIGLIORE, Alfredo Domingues Barbosa; SCALQUETTE, Ana Cláudia; LIMA, Cíntia Rosa Pereira de; BERGSTEIN, Gilberto (Coord.). Dignidade da Vida Humana. São Paulo: LTr, 2010.

LIMA, Cíntia Rosa Pereira de. Aspectos constitucionais relativos ao prolongamento artificial da vida. In: MIGLIORE, Alfredo Domingues Barbosa; SCALQUETTE, Ana Cláudia; LIMA, Cíntia Rosa Pereira de; BERGSTEIN, Gilberto (Coord.) Dignidade da vida humana. São Paulo: LTr, 2010.

MATAS, Arthur. Living kidney donation: controversies and realities: organs without borders: open markets, closed systems and the global search for living donors. Program and abstracts of the American Transplant Congress 2005. In: Sixth Annual Joint Meeting of the American Society of Transplant Surgeons and the American Society of Transplantation. Seattle (Wa), 21 a 25 de maio de 2005. Disponível em: <http://www3.interscience.wiley.com/journal/118717694/abstract>. Acesso em: 07 abr. 2010.

MCGIVERING, Jill. China 'selling prisoners'organs'. In: BBC News. Disponível em: $<$ http://news. bbc.co.uk/go/pr/fr/-/2/hi/asia-pacific/4921116.stm>. Acesso em: 07 abr. 2010.

MIGLIORE, Alfredo Domingues Barbosa; SCALQUETTE, Ana Cláudia; LIMA, Cíntia Rosa Pereira de; BERGSTEIN, Gilberto (Coord.) Dignidade da vida humana. São Paulo: LTr, 2010.

MIRANDA, Jorge. Manual de direito constitucional. 3. ed. rev. e atual. Coimbra: Ed. Coimbra, 1991. t. II e IV.

NERY JÚNIOR, Nelson; NERY, Rosa Maria de Andrade. Código civil anotado e legislação extravagante. São Paulo, Revista dos Tribunais, 2003.

POTTER, Van Rensselaer. Bioethics: bridge to the future. Englewood Cliffs (Nova Jersey): PrenticeHall, 1971. 
SCHEPER-HUGHES, Nancy. Living kidney donation: controversies and realities: organs without borders: open markets, closed systems and the global search for living donors. Program and abstracts of the American Transplant Congress 2005. In: Sixth Annual Joint Meeting of the American Society of Transplant Surgeons and the American Society of Transplantation. Seattle (Wa), 21 a 25 de maio de 2005. Disponível em: <http://www3.interscience.wiley.com/journal/118717694/abstract>. Acesso em: 07 abr. 2010.

SILVA, José Afonso da. Curso de direito constitucional positivo. São Paulo: Revista dos Tribunais, 1998.

SINGER, Peter. Practical Ethics. 2. ed. Cambridge (UK): Cambridge University Press, 1993.

VATICANO. Papa João Paulo II. Encyclical Letter To the Bishops Priests and Deacons Men and Women religious lay Faithful and all People of Good Will on the Value and Inviolability of Human Life on the value and inviolability of human life. 25 de março de 1995. Disponível em: <http://www. vatican.va/holy_father/john_paul_ii/encyclicals/documents/hf_jp-ii_enc_25031995_evangeliumvitae_en.html>.Acesso em: 07 abr. 2010. 